\title{
Policy Implementation Performance of Primary School Leaders in Malaysia: An Exploratory Factor Analysis
}

\author{
Noryati Alias \\ School of Education and Cognitive Sciences, \\ Asia e University, \\ Selangor, Malaysia \\ noryati.alias@aeu.edu.my
}

\author{
Zainudin Awang \\ Faculty of Economics and Management Sciences, \\ Universiti Sultan Zainal Abidin, \\ Terengganu, Malaysia \\ zainudinawang@unisza.edu.my
}

\author{
Habsah Muda \\ Faculty of Economics and Management Sciences, \\ Universiti Sultan Zainal Abidin, \\ Terengganu, Malaysia \\ habsah_muda@unisza.edu.my
}

\begin{abstract}
The aim of this study is to develop a scale for assessing the policy implementation performance of public primary school leaders in Malaysia. The "Implementation Leadership Scale (ILS)" by Aarons, Ehrhart and Farahnak (2014) and part of the "Teacher's Competency Scale" by Ghafar (2015) were adapted and customised to suit the context of the study in measuring school leaders' policy implementation performance. The respondents were 228 senior primary school leaders who included headmasters and senior teacher assistants in three categories: academic, student affairs, and co-curriculum. Clustered random sampling was used to select the respondents. Results of the exploratory factor analysis (EFA) revealed six underlying components of policy implementation performance with 38 indicators, the first four of which are proactive, knowledgeable, supportive, and perseverance implementation leadership. The last two components are ability to perform and standard of performance. Evidently, the six components explained $65.1 \%$ of the total variance. The reliability of the policy implementation performance construct was 0.95 , while that of other constructs ranges from 0.79 to 0.89 . In addition to contributing further insight to the current literature on policy implementation performance, the results also provide a reliable source of information to researchers and professional practitioners of educational policies for future research in policy implementation performance.
\end{abstract}

Keywords: Educational policy, policy implementation, policy implementation performance, implementation leadership, scale development

\section{INTRODUCTION}

A major success factor for a country's educational system is its educational policies (Machin, McNally \& Wyness, 2013). Up to now, in the last decade, much of the push for systemic or total educational reforms around the world has stemmed from the recognition of the positive changes the reforms had brought to society's social and economic status (Santos, 2012). 
Schools are expected to produce students with compelling thinking and problem-solving skills, and to redouble their ability to adapt to the rapidly changing world of the workplace. Hence, transforming the structure of a country's education system via educational policies should allow schools to better meet the needs of students for the 21 st century. The educational policies created shall not only raise students' academic achievement, but should also equip them with the skills required to become powerful contributors to the country's economic growth and competitiveness. Having faith that an educated citizen is an essential asset for the country, the Malaysian government has created a sound and strong educational system, and has put in place good educational reforms and policies for the people. According to Ball (2017), policies will help create equal opportunities for the people of a country to develop their character and behaviour of good citizenship.

Essentially, implementation is the third stage of a policy development cycle, after agendasetting and policy formulation (Jenkins, 1978), and to end the cycle is the stage of policy evaluation and termination. Policy implementation is a process of placing the statements of the policy into concrete actions by carrying out, undertaking, completing, and achieving the policy objectives and outcomes. Van Alfen (1993) states that the nature of policy implementation is important because when policies are being implemented correctly, it creates motivation and empowerment rather than restrictions and controls.

Policymakers and scholars have wrestled with the challenges of policy implementation for more than half a century (Moulton \& Sandfort, 2017). Because school leaders are policy implementers, many researchers found that the school leaders did not talk about policy or policy implementation in the ways that the researchers would have expected. As a substitute, the school leaders' discussions on policy and policy implementation were completely intertwined with the discussion of their daily lives as school leaders (Young \& Lewis, 2015). The implementation of policies certainly has its challenges and obstacles in achieving policy success as policy implementation operates through a complex system of social and political interactions (May \& Jochim, 2013; O'Toole, 1986). Placed at the intersection of management and policy, the implementation activities that frequently include changes in the operations of a school system and the target groups are demanding duties for school leaders.

Policy implementation has remained a significant issue since the 1970s (Pierce, Willy, Roncace, \& Bischoff, 2014; Saetren, 2014). McLaughlin (1987) argues that changes are not created or implemented by organisations, but rather by the individuals and the incentives given. Implementation is a rational process that can be planned, programmed, and controlled by policy formulators and implementers; thus, Matland (1995) concludes that "service deliverers ultimately determine the policy" (p. 148). The desired outcome of any policy implementation process is the success of attaining the policy goals.

Policy implementation requires the act of translating the goals and objectives of a policy into action. Although policy implementation is seen as an integral part of the policy cycle, ample research is lacking in this area (Shahriar \& Khan, 2016). Klein and Sorra (1996) conclude that most policies fall short not because of poor policy design, but because of the implementation failure or lean implementation. All implementation practices appear to encounter struggles and obstacles (Fixsen, Blase, Naoom \& Wallace, 2009). Hence, the 
implementation part of a policy is considered as a process, output, and outcome that involves numerous actors, organisations, and techniques for control. It is a process of myriad interactions between people who set the goals and people whose actions are directed towards achieving them (Sabatier, 1988). Policies must be implemented appropriately to realise their benefits to the society.

In this research, the third idea that is connected to the phrase policy implementation is "performance". There are research studies on policy implementation, but studies on policy implementation performance are hard to find in the current literature. Performance is a wideranging concept. It is visible on different levels and in various forms (Borman \& Motowidlo, 1997; Yammarino et al., 2008). Performance refers to the degree of achievement of goals or the possible achievement of relevant stakeholders to attain the crucial characteristics of the organisation (Krause, 2005). Hence, the source for performance is the actions of players in the process. Regarding the field of policy implementation, performance can be regarded as achievement towards the policy goals that were formulated and inspired by the government.

Ensuring that policy implementation is conducted properly is a serious imperative and a serious undertaking. Failure to achieve policy outcomes may cause a country to land in a state of financial waste and surplus, political dissatisfaction and disruption in achieving standards of well-being for its people. Without exception, the Malaysia Education Blueprint 2013-2025 too commands public school leaders in the country to be responsible for its implementation. As school is considered a unit of change (Hauge, Norenes \& Vedoy, 2014; Kaniuka, 2012; Wrigley, 2011; Hopkins, 1994), the stakeholders in schools should be principally accountable for policy implementation performance. Thereupon, school leaders must execute their performance effectively in the policy implementation stage to ensure the success of the educational policies. Attaining policy outcomes does not only depend on the effectiveness of the system, but it also relies on how people manage and perform the policy implementation process (Brinkerhoff \& Crosby, 2002).

Education policy is always a high-up issue in the agenda of governments across the world (Stevenson, 2006). Systematic educational policy is considered an important medium of government programmes that shapes and improves a nation's economy and society (Brian, 2007). Policy goals cannot be achieved if the people responsible for implementing the policy are ineffective in translating the policy goals and objectives into action. Policies must be implemented appropriately to realise the policy outcomes into success. To add to the importance of conducting research on policy implementation performance among school leaders in Malaysia, Bush, Ng, Abdul-Hamid and Kaparou (2018) found that policy implementation initiatives in Malaysia are halted because of the poor implementation performance at the school level. More specifically, in the literature on policy implementation performance, no instrument is found by the researcher to measure the policy implementation performance of policy implementers. 


\section{Objectives and Rationale of the Study}

The aim of this research is to explore and determine the factor structure of an instrument that the researcher developed to measure the policy implementation performance of public primary school leaders in Malaysia. The specific objectives of the study are two-fold. They are:

1. To determine whether the items measuring the policy implementation performance construct were suitable and comprise an interpretable underlying factor structure; and

2. To ascertain the reliability and the validity of the factor structure that represents the belief of the public primary school leaders on policy implementation performance.

Thus, establishing the factor structure that influences the success of the policy implementation performance construct is essential, appropriate and commendable.

\section{Theoretical Framework}

Paradoxically, there is no grand theory for policy implementation, and this obfuscates what implementation is and is not (Goggin, Bowman, Lester, \& O' Toole, 1990). Goggin et al. (1990) believe that the one reason for the absence of such a grand theory for implementation is because this field of study is still in its infancy as a discipline. However, based on the contextual premises mentioned concerning precise policy implementation performance, Shahriar and Khan (2016) theorised five models to accelerate policy implementation performance. The models of policy implementation performance consist of a rational, management, organisational development, bureaucratic and political model. However, the models proposed have not been tested empirically.

The rational model of successful policy implementation is based on the belief that policy implementation needs clear goals, missions and objectives, comprehensive planning, proper job assignments, effective monitoring and evaluation, complete and efficient operating procedures, and methods that support policy implementers to delineate their responsibilities coherent with the policy objectives. Meanwhile, the management model posits that performing policy implementation is influenced by factors such as organisational structure, personnel and human resources, the activities of front-line implementers, equipment and technology, the level of coordination and cooperation, the exercise of authority, and the location as the implementation infrastructure. By using the management model, the problems and obstacles that impede policy implementation, such as the shortage of resources or delays to get the resources, may be identified.

Conversely, the organizational development model of implementation performance believes that the performance of policy implementation depends on the organisational leadership capacity, team building, the engagement of the various parties involved, participation, motivation, coordination and commitment. In comparison, the bureaucratic model of policy implementation performance appreciates the role of front-line staff members in the 
organisations since successful policy implementation strongly depends on the roles of staff who directly get into contact with people and other stakeholders pertinent to the organisation. This model is proposed to establish the social reality regarding the discretionary power of frontline implementers of policy. This model originates from the concept of the bottom-up theory of policy implementation.

\section{Conceptual Framework}

Aarons, Ehrhart and Farahnak (2014) posit that both implementation and leadership theories emphasise the importance of leadership in supporting policy implementation. The four factors that made up the implementation leadership as specified by Aarons et al. (2014) were based on the degree to which a leader is proactive to policy implementation, the leader's knowledge of policy and implementation, his/her support for policy implementation, and perseverance in the policy implementation process. In addition, Ghafar (2015) reckons that teachers must be competent to implement policies, such as adhering to the standards of performance and have the ability to perform. Therefore, the researcher had chosen six important sub-dimensions from Aarons et al. (2014) and Ghafar (2015) to develop an instrument measuring policy implementation performance construct. The six dimensions are proactive, knowledgeable, supportive, perseverance, standards of performance, and ability to perform. Figure 1 illustrates the conceptual framework of the policy implementation performance construct assessed in this study.

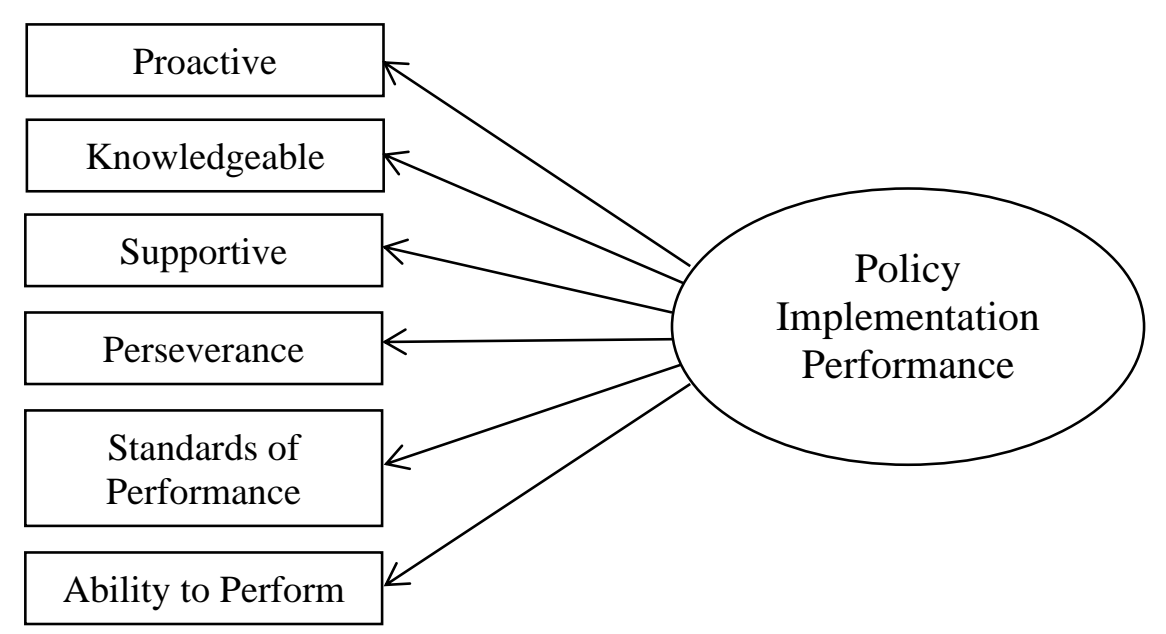

Figure 1: Conceptual Framework of Primary School Leaders' Policy Implementation Performance

\section{METHODOLOGY}

\section{Research Design}

This study adopts the quantitative and ex-post facto research design since it examines the correlations between variables as they naturally occur in the population of interest, establishes the cause and effect in highly controlled circumstances, and testing the theories or hypotheses 
(Sekaran \& Bougie, 2016). To address the two research objectives, the cross-sectional survey method was utilised. The survey entailed the administration of a questionnaire that sought to gain data on the current perceptions of public primary school leaders in Malaysia on their policy implementation performance at a specific point in time.

\section{Population and Sample}

As in the year 2018, the number of public primary schools were 7,772, representing about $76.1 \%$ of the public schools' population in Malaysia. The Malaysian government finances these public schools to ensure that every child in the country has access to free education at the primary and secondary education levels. Hence, the ideal population of this research comprised school leaders who were serving in public primary schools, whose number totaled 31,088 respondents. A sample of 520 headmasters and senior teacher assistants was then selected from this pool of primary school leaders' population. However, only 228 school leaders responded fully to the given questionnaire.

\section{Sampling Procedures}

Cluster sampling based on five regions (or clusters) in Malaysia was employed to select the sample of primary school leaders. Five states were chosen randomly to represent the five clusters or regions. The states were: Kedah (representing the northern region of Peninsular Malaysia), Pahang (representing the eastern region of Peninsular Malaysia), Malacca (representing the southern region of Peninsular Malaysia), Selangor (representing the central region of Peninsular Malaysia), and Sabah (representing East Malaysia). Cluster sampling is appropriate when the research crosses a large geographical area. After the states were determined, simple random sampling was employed to choose the public primary schools in the District Education Departments of each selected state.

\section{Instrument}

A self-administered questionnaire comprising thirty-eight (38) closed-ended Likert questions was used to gather the perceptions of public primary school leaders in Malaysia regarding their respective policy implementation performance. The "Implementation Leadership Scale (ILS)" by Aarons et al. (2014) and part of the "Teacher's Competency Scale" by Ghafar (2015) were adapted and customised to suit the context of the study in measuring the policy implementation performance of public primary school leaders in Malaysia. The 38 items measuring policy implementation performance were presented on a 10-point interval scale ranging from " $1=$ Strongly Disagree" to " $10=$ Strongly Agree".

\section{Data Collection}

The survey was administered manually. The respondents were given a self-addressed stamped 
envelope in which to return the completed questionnaire to the researcher. Prior to the questionnaire distribution, the researcher had acquired a research approval from the Educational Planning and Research Department (EPRD) of Malaysia's Ministry of Education, as well as from the Education Department of the five identified states. A total of two-hundred thirty-three (233) cases were collected from the 520 distributed. However, five questionnaires were discarded due to incomplete responses that constituted more than $10 \%$ of missing data. The total number of cases finalized for the analysis was 228 with a response rate of about 43.8 percent.

\section{Data Analysis}

Data from the 228 school leaders were subjected to the procedures of Principal Component Analysis (PCA) with Varimax rotation (Gaskin \& Happell, 2014) since this rotation method extracts factors based on the correlation among the items. The Varimax was chosen over the Oblimin since the factors were independent of each other. Furthermore, PCA is suggested to be used when no prior theoretical basis or model exists (Gorsuch, 1990). In addition, the use of PCA is recommended in determining preliminary solutions in EFA (Pett, Lackey, \& Sullivan, 2003).

To examine the appropriateness of the data for running factor analysis, the Kaiser-MeyerOlkin Measure of Sampling Adequacy (KMO) and Bartlett's Test of Sphericity (BTOS) were checked. A KMO value of 0.60 and above (Kaiser, 1974; Pallant, 2016; Tabachnick \& Fidell, 2007) and a statistically significant Bartlett's Test of Sphericity (Bartlett, 1950) were used as indicators of data factorability. The KMO test also checks for multicollinearity among the items, while the Bartlett's test identifies the correlation among the items (Chua, 2009). The acceptance of Bartlett's test depends on the value of significance. If the significance value nears $0.0(\mathrm{p}<0.05)$, the items are judged suitable for the conduct of factor analysis (Awang, 2012).

Other guidelines used for the PCA were: (1) factors must have an eigenvalue greater than 1; (2) for practical significance, items should have a factor loading greater than 0.50 ; (3) no item cross-loading greater than 0.50 should be accepted. However, this study had opted to retain items with factor loadings greater than 0.60 since the items in the questionnaire were initially adapted from a pool of established items (Awang, 2012); and (4) the number of items per factor must be at least three for the factor to be retained (Hair et al., 2010). The scree plot (Cattell, 1966) was also referred to in determining the number of factors to be retained since the study had a sample size higher than 200 (Steven, 2012).

For the category of absolute number of cases, the 'Rule of 100' is followed, where to perform EFA there must be at least a minimum of 100 cases (Gorsuch, 1990; Kline, 2010; MacCallum, Widaman, Zhang \& Hong; 1999). This research used a sample size of $N=228$ to conduct the EFA analysis. The steps in conducting the EFA for the policy implementation performance construct are illustrated in Figure 2. After a comprehensive data cleaning and screening process, the 228 responses were found to be valid; they were subsequently analysed using IBM-SPSS 21.0 for Exploratory Factor Analysis. The EFA results for the policy implementation performance construct are presented in the Results section. 


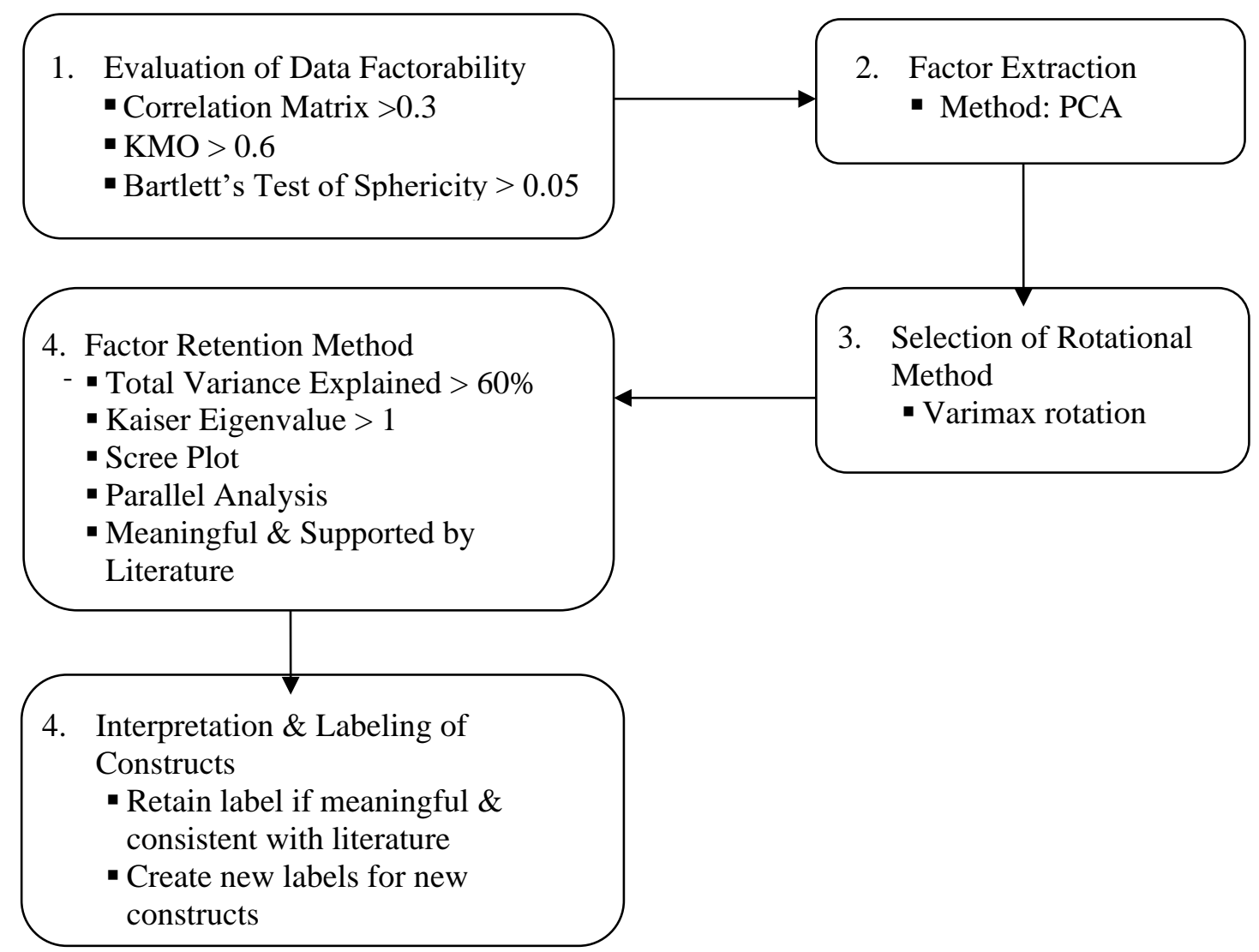

Figure 2: Steps for the Exploratory Factor Analysis

\section{Reliability Analysis}

A construct must also be reliable. Reliability of a construct or variable refers to its consistency, stability, and dependency of the scores in the questionnaire. The construct or the variable that is being measured must be stable or constant. According to Sekaran and Bougie (2016), the reliability of a measure is achieved when it consistently, and without bias, measures the concept it is supposed to measure. On this ground, the reliability of the policy implementation construct was estimated using the internal consistency reliability. The coefficient of internal consistency gives an estimate of the reliability of the measurement and is constructed on the belief that items determining the same construct ought to correlate. Nunnally (1978) recommended that an acceptable level of coefficient alpha to maintain an item on a scale is at least 0.70 .

\section{RESULTS}

The policy implementation performance construct was measured using 38 items in the questionnaire; using the interval score from 1 (Strongly Disagree) to 10 (Strongly Agree). In this study, the policy implementation performance construct was measured initially by six subdimensions: (1) proactive (PRO), (2) knowledgeable (KNO), (3) supportive (SUP), (4) perseverance (PER), (5) ability to perform (AB), and (6) standard of performance (SOP). 


\section{Descriptive Statistics for the Factor Structure}

Table 1 shows the descriptive statistics, that includes the number of items, means and standard deviations of the six extracted factors. Supportive has the lowest mean $(M=4.800$ while perseverance has the highest mean value $(M=5.30)$. The standard deviation for the six subconstructs is not more than two standard deviations of the mean, indicating that the data collected for policy implementation performance are clustered tightly around the mean and reliable.

Table 1:

Descriptive Statistics of the Factor Structure (N=228)

\begin{tabular}{clccc}
\hline No. & \multicolumn{1}{c}{ Sub-Construct } & No. of Items & Mean & SD \\
\hline 1 & Proactive & 6 & 4.83 & .763 \\
2 & Knowledgeable & 5 & 5.21 & .838 \\
3 & Supportive & 6 & 4.80 & .844 \\
4 & Perseverance & 7 & 5.30 & .856 \\
5 & Ability to Perform & 6 & 4.84 & .851 \\
6 & Standard of Performance & 8 & 4.68 & .844 \\
\hline
\end{tabular}

\section{Exploratory Factor Analysis Results}

The value of the KMO for the policy implementation performance construct was 0.934 (marvellous); higher than the threshold value of 0.5 (Kline, 1994; Tabachnick \& Fidell, 2007; Hair et al., 2010; George \& Mallery, 2001). The Bartlett's Test of Sphericity was also significant $($ Chi-square $=5123.706$, p-value $<0.001)$. Since the KMO value is close to 1.0 and the significance value of Bartlett's Test of Sphericity is near to 0.0, it can be reckoned that the policy implementation performance construct with 38 items is factorable and adequate to proceed with factor analysis (see Table 2). An examination of the correlation matrix among items that assess policy implementation performance construct exhibited many coefficients of 0.3 and above.

Table 2:

KMO and Bartlett's Test for Policy Implementation Performance Construct

\begin{tabular}{lcc}
\hline \multicolumn{3}{c}{ KMO and Bartlett's Test } \\
\hline Kaiser-Meyer-Olkin Measure of Sampling Adequacy. & .934 \\
\hline \multirow{3}{*}{ Bartlett's Test of Sphericity } & Approx. Chi-Square & 5123.706 \\
& df & 703 \\
& Sig. & .000
\end{tabular}

Table 3 displayed the PCA with Varimax rotation result for 38 items under policy implementation performance construct. The results demonstrate that the PCA procedure has extracted six components with eigenvalues exceeding the value of 1.0, with the total variance explained for all six components to be $65.09 \%$, greater than the recommended sixty percent for a construct to be valid. Evidently, the six components explained $65.09 \%$ of the total 
variance; where Component 1 contributes 12.44\%, Component $211.75 \%$, Component 3 $11.000 \%$, Component 4 10.77\%, Component $510.05 \%$, and Component 6 contributes $9.08 \%$.

Table 3:

Total Variance Explained for Policy Implementation Performance Construct

\begin{tabular}{|c|c|c|c|c|c|c|c|c|c|}
\hline \multicolumn{10}{|c|}{ Total Variance Explained } \\
\hline \multirow{2}{*}{ 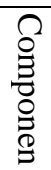 } & \multicolumn{3}{|c|}{ Initial Eigenvalues } & \multicolumn{3}{|c|}{$\begin{array}{l}\text { Extraction Sums of Squared } \\
\text { Loadings }\end{array}$} & \multicolumn{3}{|c|}{ Rotation Sums of Squared Loadings } \\
\hline & Total & $\begin{array}{c}\% \text { of } \\
\text { Variance }\end{array}$ & $\begin{array}{c}\text { Cumulative } \\
\%\end{array}$ & Total & $\begin{array}{c}\% \text { of } \\
\text { Variance }\end{array}$ & $\begin{array}{c}\text { Cumulative } \\
\%\end{array}$ & Total & $\begin{array}{c}\% \text { of } \\
\text { Variance }\end{array}$ & Cumulative $\%$ \\
\hline 1 & 13.112 & 34.506 & 34.506 & 13.112 & 34.506 & 34.506 & 4.728 & 12.442 & 12.442 \\
\hline 2 & 2.815 & 7.407 & 41.913 & 2.815 & 7.407 & 41.913 & 4.464 & 11.747 & 24.189 \\
\hline 3 & 2.473 & 6.507 & 48.420 & 2.473 & 6.507 & 48.420 & 4.180 & 11.000 & 35.189 \\
\hline 4 & 2.274 & 5.985 & 54.406 & 2.274 & 5.985 & 54.406 & 4.094 & 10.773 & 45.963 \\
\hline 5 & 2.105 & 5.541 & 59.946 & 2.105 & 5.541 & 59.946 & 3.820 & 10.053 & 56.015 \\
\hline 6 & 1.956 & 5.148 & 65.094 & 1.956 & 5.148 & 65.094 & 3.450 & 9.078 & 65.094 \\
\hline
\end{tabular}

The scree plot for the policy implementation performance construct had sorted the 38 items neatly into six components (see Figure 3). The examination of the scree plot shows an obvious point of inflation after the sixth factor.

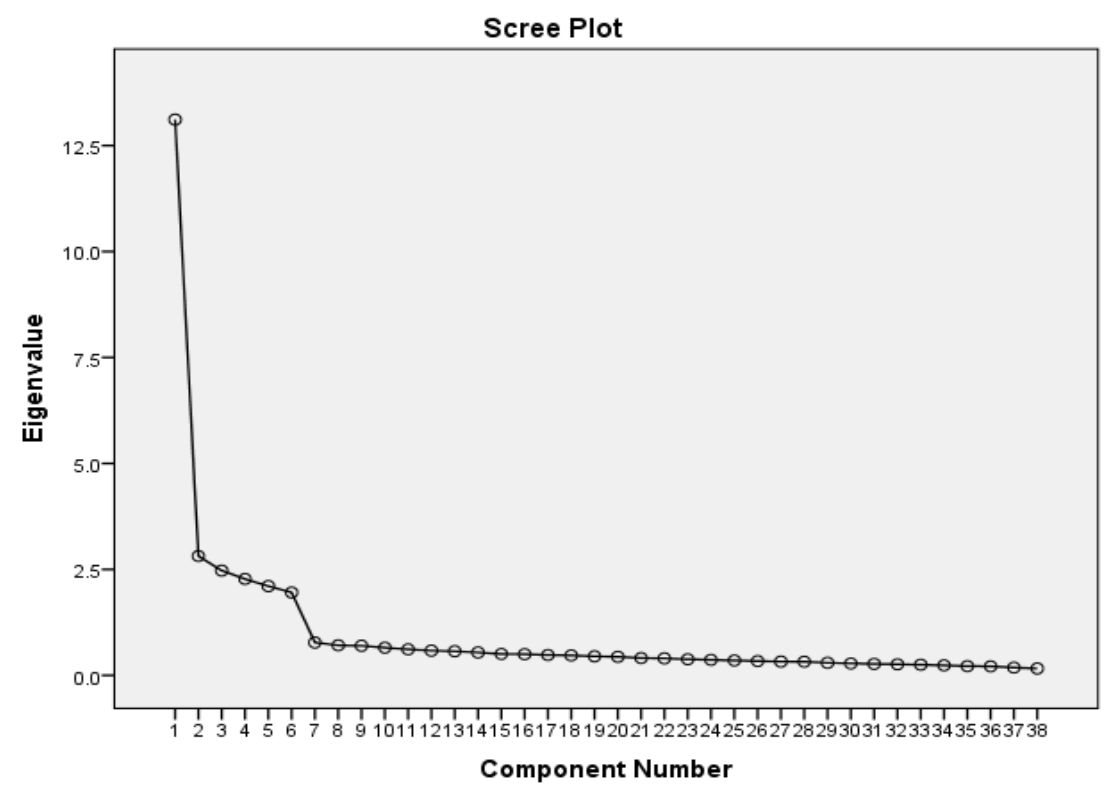

Figure 3: Scree Plot for Policy Implementation Performance Construct

In addition, the results of a parallel analysis (Table 4) for policy implementation performance construct supports the acceptance of six components from the scree plot since the eigenvalues of the actual data go beyond the eigenvalues in the simulative data. It rejects Component 7 from the parallel analysis, since the eigenvalue of the simulative data is larger than the eigenvalue of the real data. 
Table 4:

Parallel Analysis for Policy Implementation Performance Construct

\begin{tabular}{cccc}
\hline $\begin{array}{c}\text { Component } \\
\text { Number }\end{array}$ & $\begin{array}{c}\text { Actual Eigenvalue } \\
\text { from PCA }\end{array}$ & $\begin{array}{c}\text { Criterion Value } \\
\text { from Parallel Analysis }\end{array}$ & Decision \\
\hline 1 & 13.112 & 1.8725 & Accept \\
2 & 2.815 & 1.7561 & Accept \\
3 & 2.473 & 1.6760 & Accept \\
4 & 2.274 & 1.6122 & Accept \\
5 & 2.105 & 1.5517 & Accept \\
6 & 1.956 & 1.5015 & Accept \\
7 & 0.775 & 1.4446 & Reject \\
\hline
\end{tabular}

The rotated component matrix results for the policy implementation performance construct suggested a six-component solution, as showed in Table 5. The 38 items collapse neatly into six components that measure policy implementation performance. All items have factor loadings greater than 0.6. There were no cross-loadings of items among the six components. Hence, the results allowed the study to retain the six constructs as they are named in policy implementation performance literature. Table 5 shows the final EFA results for policy implementation performance construct with 38 items and its factor loadings

Table 5:

Final EFA Result for Policy Implementation Performance Construct

\begin{tabular}{|c|c|c|c|c|c|c|c|c|}
\hline \multirow{3}{*}{ Sub-Construct } & \multirow{3}{*}{$\begin{array}{l}\text { Item } \\
\text { Label }\end{array}$} & \multicolumn{7}{|c|}{ Rotated Component Matrix ${ }^{a}$} \\
\hline & & \multirow[t]{2}{*}{ Item Statement } & \multicolumn{5}{|c|}{ Component } & \multirow[b]{2}{*}{6} \\
\hline & & & 1 & 2 & 3 & 4 & 5 & \\
\hline \multirow[t]{7}{*}{ Perseverance } & PER1 & $\begin{array}{l}\text { I endure through the ups and downs of } \\
\text { implementing policies. }\end{array}$ & .675 & & & & & \\
\hline & PER2 & $\begin{array}{l}\text { I face the challenges of implementing } \\
\text { policies. }\end{array}$ & .748 & & & & & \\
\hline & PER3 & $\begin{array}{l}\text { I deal with problems regarding the } \\
\text { implementation of the policies. }\end{array}$ & .763 & & & & & \\
\hline & PER4 & $\begin{array}{l}\text { I react effectively to critical issues regarding } \\
\text { the implementation of the policies. }\end{array}$ & .766 & & & & & \\
\hline & PER5 & $\begin{array}{l}\text { I overcome setbacks in implementing } \\
\text { policies. }\end{array}$ & .708 & & & & & \\
\hline & PER6 & $\begin{array}{l}\text { I finish whatever I begin in implementing } \\
\text { policies. }\end{array}$ & .736 & & & & & \\
\hline & PER7 & $\begin{array}{l}\text { I am persistent in facing difficult situations } \\
\text { when implementing policies. }\end{array}$ & .753 & & & & & \\
\hline \multirow[t]{7}{*}{$\begin{array}{l}\text { Standard of } \\
\text { Operating }\end{array}$} & SOP1 & $\begin{array}{l}\text { I implement the policies as a guide to achieve } \\
\text { minimum performance at school. }\end{array}$ & & .730 & & & & \\
\hline & SOP2 & $\begin{array}{l}\text { I implement the policies as a guide to obtain } \\
\text { competencies needed to achieve school's } \\
\text { vision. }\end{array}$ & & .689 & & & & \\
\hline & SOP3 & $\begin{array}{l}\text { I implement the policies as a guide to manage } \\
\text { the changes in school }\end{array}$ & & .748 & & & & \\
\hline & SOP4 & $\begin{array}{l}\text { I implement the policies as a guide to set the } \\
\text { required standard for me to meet the school' } \\
\text { performance. }\end{array}$ & & .743 & & & & \\
\hline & SOP5 & $\begin{array}{l}\text { I implement the policies as a guide to } \\
\text { motivate myself to achieve my own goals. }\end{array}$ & & .723 & & & & \\
\hline & SOP6 & $\begin{array}{l}\text { I implement the policies as a guide to achieve } \\
\text { productivity in my school. }\end{array}$ & & .758 & & & & \\
\hline & SOP7 & $\begin{array}{l}\text { I implement the policies as a guide to } \\
\text { improve my performance in school }\end{array}$ & & .742 & & & & \\
\hline
\end{tabular}




\begin{tabular}{|c|c|c|c|c|c|c|c|c|}
\hline \multirow{3}{*}{ Sub-Construct } & \multirow{3}{*}{$\begin{array}{l}\text { Item } \\
\text { Label }\end{array}$} & \multicolumn{7}{|c|}{ Rotated Component Matrix $^{\mathrm{a}}$} \\
\hline & & \multirow[t]{2}{*}{ Item Statement } & \multicolumn{5}{|c|}{ Component } & \multirow[b]{2}{*}{6} \\
\hline & & & 1 & 2 & 3 & 4 & 5 & \\
\hline $\begin{array}{l}\text { Standard of } \\
\text { Operating }\end{array}$ & SOP8 & $\begin{array}{l}\text { I implement the policies as a guide to fulfil } \\
\text { my responsibilities at school. }\end{array}$ & & .71 & & & & \\
\hline \multirow[t]{12}{*}{ Ability to Perform } & $\mathrm{AB} 1$ & $\begin{array}{l}\text { I complete the tasks mentioned in the } \\
\text { policies. }\end{array}$ & & & .721 & & & \\
\hline & $\mathrm{AB} 2$ & I take actions based on the policies. & & & .692 & & & \\
\hline & AB3 & $\begin{array}{l}\text { I work long hours to ensure the success of } \\
\text { the policies. }\end{array}$ & & & .741 & & & \\
\hline & AB4 & $\begin{array}{l}\text { I communicate effectively regarding the } \\
\text { policies to my subordinates. }\end{array}$ & & & .764 & & & \\
\hline & AB5 & $\begin{array}{l}\text { I justify the functions of policies in my } \\
\text { school. }\end{array}$ & & & .778 & & & \\
\hline & AB6 & $\begin{array}{l}\text { I implement plans for my school with } \\
\text { regard to the policies. }\end{array}$ & & & .784 & & & \\
\hline & PRO1 & $\begin{array}{l}\text { I always develop a plan to facilitate the } \\
\text { implementation of the policies. }\end{array}$ & & & & .765 & & \\
\hline & $\mathrm{PRO} 2$ & $\begin{array}{l}\text { I always remove the obstacles in the } \\
\text { implementation of the policies. }\end{array}$ & & & & .728 & & \\
\hline & PRO3 & $\begin{array}{l}\text { I always establish clear school standards } \\
\text { for the implementation of the policies. }\end{array}$ & & & & .722 & & \\
\hline & PRO4 & $\begin{array}{l}\text { I always constantly been on the lookout for } \\
\text { ways to implement the policies. }\end{array}$ & & & & .795 & & \\
\hline & PRO5 & $\begin{array}{l}\text { I always believe that my plans for the } \\
\text { implementation of the policies will turn } \\
\text { into reality. }\end{array}$ & & & & .735 & & \\
\hline & PRO6 & $\begin{array}{l}\text { I always identify the opportunities to } \\
\text { expedite the implementation of the } \\
\text { policies. }\end{array}$ & & & & .733 & & \\
\hline \multirow{6}{*}{ Supportive } & SUP1 & $\begin{array}{l}\text { I recognise my teachers' effort toward } \\
\text { successful implementation of the policies. }\end{array}$ & & & & & .779 & \\
\hline & SUP2 & $\begin{array}{l}\text { I appreciate my teachers' effort toward } \\
\text { successful implementation of the policies. }\end{array}$ & & & & & .730 & \\
\hline & SUP3 & $\begin{array}{l}\text { I support my teachers' effort to use the } \\
\text { policies. }\end{array}$ & & & & & .732 & \\
\hline & SUP4 & $\begin{array}{l}\text { I support my teachers' effort to learn more } \\
\text { about the policies. }\end{array}$ & & & & & .715 & \\
\hline & SUP5 & $\begin{array}{l}\text { I help my teachers' when they face } \\
\text { difficulties in implementing policies. }\end{array}$ & & & & & .796 & \\
\hline & SUP6 & $\begin{array}{l}\text { I provide resources to my teachers to } \\
\text { implement policies. }\end{array}$ & & & & & .759 & \\
\hline \multirow{5}{*}{ Knowledgeable } & KNO1 & $\begin{array}{l}\text { I am knowledgeable about the } \\
\text { implementation of the policies. }\end{array}$ & & & & & & .760 \\
\hline & $\mathrm{KNO} 2$ & $\begin{array}{l}\text { I am able to answer the questions about } \\
\text { policies from stakeholders. }\end{array}$ & & & & & & .745 \\
\hline & KNO3 & I am able to talk about the policies. & & & & & & .732 \\
\hline & KNO4 & $\begin{array}{l}\text { I am knowledgeable about the constraints } \\
\text { during the implementation of the policies. }\end{array}$ & & & & & & .729 \\
\hline & KNO5 & $\begin{array}{l}\text { I am capable in assisting my teachers to } \\
\text { implement policies. }\end{array}$ & & & & & & .754 \\
\hline
\end{tabular}

Extraction Method: Principal Component Analysis.

Rotation Method: Varimax with Kaiser Normalization.

a. Rotation converged in 8 iterations. 


\section{Reliability Analysis for Policy Implementation Performance}

The reliability estimates for the underlying constructs of policy implementation performance are presented in Table 6 . The reliability indexes range between 0.79 and 0.89 , suggesting that the items representing the constructs are strongly reliable and highly acceptable. Up to this point, the 38 items used to measure the policy implementation performance construct has a reliability value of 0.95 , implying that the items are an excellent measure of the constructs.

Table 6:

Reliability Analysis for Policy Implementation Performance Constructs

\begin{tabular}{llcc}
\hline Sub-Constructs & No of Items & $\begin{array}{c}\text { Cronbach's } \\
\text { Alpha }\end{array}$ \\
\hline 1. & Proactive & 6 & 0.867 \\
2. & Knowledgeable & 5 & 0.785 \\
3. & Supportive & 6 & 0.830 \\
4. & Perseverance & 7 & 0.880 \\
5. & Ability to Perform & 6 & 0.869 \\
6. & Standard of Performance & 8 & 0.887 \\
\hline \multicolumn{2}{r}{ Total } & 38 & 0.949 \\
\hline
\end{tabular}

\section{DISCUSSION AND CONCLUSION}

Results from this study reveal that the scale to measure policy implementation performance of public primary school leaders in Malaysia has great reliability and validity. The policy implementation performance construct measures six-sub-constructs that correlate to the capability of the public primary school leaders in Malaysia to perform in implementing policies towards success. The content validity of the scale was established by five experts who provided their professional judgment on thirty-eight items assessing the construct of policy implementation performance. An EFA was subsequently employed to identify its underlying factor structure to establish the construct validity of policy implementation performance. The extracted factors' internal consistency was also estimated using Cronbach's alpha to determine the reliability of the scale.

The aim of this study was to develop a scale that assess the public primary school leaders' policy implementation performance in Malaysia. The analysis shows that as a construct, policy implementation performance is defined by six-interrelated sub-constructs, which in this study, were shown to demonstrate acceptable psychometric properties. The six-factor-structure discovered in the EFA demonstrates that the scale may be used to assess the capacities needed for successful policy implementation performance among primary school leaders, specifically, and other educational leaders, generally. In other words, the public primary school leaders in Malaysia should have the six capacities indicated, namely being proactive, knowledgeable, and supportive, and having perseverance and the ability to perform, in addition to observing the standard of performance in order to achieve success in their policy implementation efforts. While studies in policy implementation performance are rare in the literature, the findings of this study support the need for further research in policy implementation. 
Policy implementation is a complicated process (Signe, 2017). The directions on how policy actors and implementers act on implementation may determine whether a policy can succeed or fail. For policy goals to be materialised, Greenhalgh et al. (2004) and Fixsen et al. (2009) have insisted that organisations should not take the approach of "let it happen" in implementing any policies that make an impact on individuals and societies at large. However, at this point, the researcher found that too little attention has been given to acknowledge what constitutes the measurement of policy implementation performance.

School leaders are responsible for translating the objectives and goals of policies into action. The study indicates that six factors are needed for a successful implementation of a policy. Leaders need to be proactive, knowledgeable, and supportive. Moreover, they must have a sufficient amount of perseverance and the ability to perform, while observing the standard of performance. This study has produced a scale that lends credence to the importance of the six factors in effective policy implementation.

The validated scale is useful for practitioners as it would expand their awareness to improve the performance of policy implementers at the meso and micro levels of the process. This scale can be used to determine whether the leaders in Malaysian schools have the required capabilities to implement educational policies to the fullest in realising the country's educational policy goals. It is the responsibility of relevant government authorities, organisations, parties, and individuals to prepare the policy implementers with the essential abilities for effective policy implementation performance. To further validate the existence and contribution of the current factor structure, an extended study involving the use of confirmatory factor analysis is recommended, the aim of which is to produce a more comprehensive scale of policy implementation performance. 


\section{REFERENCES}

Aarons, G. A., Ehrhart, M. G., \& Farahnak, L. R. (2014). The implementation leadership scale (ILS): development of a brief measure of unit level implementation leadership. Implementation Science, 9(1), 45.

Awang, Z. (2012). Research methodology and data analysis. Penerbit Universiti Teknologi MARA Press.

Awang, Z. (2015). SEM made simple: A gentle approach to learning Structural Equation Modeling. MPWS Rich Publication.

Ball, S. J. (2017). The education debate. Policy Press.

Bartlett, M. S. (1950). Tests of significance in factor analysis. British Journal of Statistical Psychology, 3(2), 77-85.

Borman, W. C., \& Motowidlo, S. J. (1997). Task performance and contextual performance: The meaning for personnel selection research. Human Performance, 10(2), 99-109.

Brian, K. (2007). OECD Insights human capital how what you know shapes your life: How what you know shapes your life. OECD Publishing

Brinkerhoff, D. W., \& Crosby, B. L. (2002). Managing policy reform. Bloomfield: Kumarian Press.

Bush, T., Ng, A., Abdul-Hamid, S., \& Kaparou, M. (2018), School leadership theories and the Malaysia Education Blueprint: Findings from a systematic literature review. International Journal of Educational Management, 32 (7): 1245-1265.

Cattell, R. B. (1966). The scree test for the number of factors. Multivariate Behavioral Research, 1(2), 245-276.

Chua, Y.P. (2009). Advanced research statistics: Regression test, factor analysis and SEM analysis. Shah Alam, Malaysia: McGraw-Hill Education.

Fixsen, D. L., Blase, K. A., Naoom, S. F., Van Dyke, M., \& Wallace, F. (2009). Implementation: The missing link between research and practice. NIRN Implementation Brief, 1, 218-227.

Gaskin, C. J., \& Happell, B. (2014). On exploratory factor analysis: A review of recent evidence, an assessment of current practice, and recommendations for future use. International Journal of Nursing Studies, 51(3), 511-521

Ghafar, M. N. A. (2015). Methodology in behavioural research. Penerbit UTM Press. 
Goggin, M. L., Bowman, A. Lester, J., \& O’Toole, L. (1990). Implementation theory and practice: Toward a third generation. New York: Harper Collins.

Gorsuch, R. L. (1990). Common factor analysis versus component analysis: Some well- and little-known facts. Multivariate Behavioral Research, 25(1), 33-39.

Greenhalgh, T., Robert, G., Macfarlane, F., Bate, P., \& Kyriakidou, O. (2004). Diffusion of innovations in service organizations: Systematic review and recommendations. The Milbank Quarterly, 82(4), 581-629.

Hair, J. F. J., Black, W. C., Babin, B. J., \& Anderson, R. E. (2010). Multivariate Data Analysis Seventh Edition. Prentice Hall.

Hauge, T. E., Norenes, S. O., \& Vedøy, G. (2014). School leadership and educational change: Tools and practices in shared school leadership development. Journal of Educational Change, 15(4), 357-376.

Hopkins, M. (1994). Beliefs in context: Understanding language policy implementation at a systems level. Educational Policy, 30(4), 573-605.

Jenkins, W. I. (1978). Policy analysis: A political and organisational perspective. London: M. Robertson.

Kaiser, H. F. (1974). An index of factorial simplicity. Psychometrika, 39(1), 31-36.

Kaiser, H. F. (1960). Varimax solution for primary mental abilities. Psychometrika, 25(2), 153158.

Kaniuka, T. S. (2012). Toward an understanding of how teachers change during school reform: Considerations for educational leadership and school improvement. Journal of Educational Change, 13(3), 327-346.

Kline, P. (1994). An easy guide to factor analysis. Abingdon-on-Thames Routledge.

Kline, R. B. (2010). Promise and pitfalls of structural equation modeling in gifted research.

Klein, K. J., \& Sorra, J. S. (1996). The challenge of innovation implementation. Academy of Management Review, 21(4), 1055-1080.

Krause, O. (2005). Performance measurement-Eine stakeholder-nutzen-orientierte und und geschaftsprozess-basierte methode. Berlin: Technische Universitat.

MacCallum, R. C., Widaman, K. F., Zhang, S., \& Hong, S. (1999). Sample size in factor analysis. Psychological Methods, 4(1), 84. 
Machin, S., McNally, S., \& Wyness, G. (2013). Educational attainment across the UK nations: performance, inequality and evidence. Educational Research, 55(2), 139-164.

Matland, R.E. (1995). Synthesizing the implementation literature: The ambiguity-conflict model of policy implementation. Journal of Public Administration Research and Theory, vol. 5, no. 2, pp. 145-174.

May, P. J., \& Jochim, A. E. (2013). Policy regime perspectives: Policies, politics, and governing. Policy Studies Journal, 41(3), 426-452.

McLaughlin, M. W. (1987). Learning from experience: Lessons from policy implementation. Educational Evaluation and Policy Analysis, 9(2), 171-178.

Moulton, S., \& Sandfort, J. R. (2017). The strategic action field framework for policy implementation research. Policy Studies Journal, 45(1), 144-169.

Nunnally, J.C. (1978). Psychometric theory, 2nd edition. New York: McGraw-Hill.

O’Toole, L. J. (1986). Policy recommendations for multi-actor implementation: An assessment of the field. Journal of Public Policy, 6(2), 181-210.

Pallant, J. S. P. S. S. (2016). Survival manual: A step by step guide to data analysis using SPSS program. London: McGraw-Hill.

Pett, M. A., Lackey, N. R., \& Sullivan, J. J. (2003). Making sense of factor analysis: The use of factor analysis for instrument development in health care research. Sage.

Pierce, T. P., Willy, C., Roncace, R., \& Bischoff, J. (2014). Extending the technology acceptance model: Policy acceptance model (PAM). American Journal of Health Sciences (AJHS), 5(2), 129-144.

Sabatier, P. A. (1988). An advocacy coalition framework of policy change and the role of policy-oriented learning therein. Policy Sciences, 21(2-3), 129-168.

Saetren, H. (2014). Implementing the third-generation research paradigm in policy implementation research: An empirical assessment. Public Policy and Administration, 29(2), 84-105.

Santos, A. (2012). Considerations for education reform in British Columbia. Canadian Journal of Educational Administration and Policy.

Sekaran, U., \& Bougie, R. (2016). Research methods for business: A skill building approach. John Wiley \& Sons.

Shahriar, K., \& Khan, A. (2016). A Critical Insight into Policy Implementation and Implementation Performance. Viesoji Politika ir Administravimas, 15(4). 
Signe, L. (2017). Policy implementation - A synthesis of the study of policy implementation and the causes of policy failure (No. 1703). OCP Policy Center.

Stevenson, H. (2006). Education policy: Process, themes and impact. Taylor \& Francis

Tabachnick, B. G., \& Fidell, L. S. (2007). Using multivariate statistics. Allyn \& Bacon/Pearson Education.

Wrigley, T. (2011). Paradigms of school change. Management in Education, 25(2), 62-66.

Van Alfen, C. (1993). School board policy as an instrument of empowering leadership in America. Paper presented at the 2nd Annual Conference on Creating Quality Schools, Oklahoma City, Oklahoma, March 25 - 27.

Yammarino, F. J., Dionne, S. D., Schriesheim, C. A., \& Dansereau, F. (2008). Authentic leadership and positive organizational behavior: A meso, multi-level perspective. The Leadership Quarterly, 19(6), 693-707.

Young, T., \& Lewis, W. D. (2015). Educational policy implementation revisited. 